\title{
Gender Responsive Budgeting in the Local Self-Government in the Republic of Serbia
}

\author{
Zvonko Brnjas $^{1}$ \\ Institute of Economic Sciences, Belgrade, Serbia \\ Mihajlo Đukić ${ }^{2}$ \\ Institute of Economic Sciences, Belgrade, Serbia
}

\section{A B S T R A C T}

Gender equality and gender non-discrimination issues belong to the set of basic principles of human rights being a very relevant research topic in many developed countries worldwide. To the large extent, this issue is becoming increasingly important in less developed economies including the Republic of Serbia. In this paper, the focus will be on one specific aspect of gender equality - gender sensitive or gender responsive budgeting in the local self-government units. Considering that economic equality is almost always a pre-condition for any other equality, success in incorporating the gender equality concept into the budgetting process might determine the nature of relationship between the genders. This also (as the most frequent manifestation of these relationships) includes the position of women in local communities. Special attention in the paper will be paid to development and functioning of the institutional mechanisms for the achivement of gender equality, as well as specifics of gender responsive budgeting in the local selfgovernments in Serbia.

KEY WORDS: Gender responsive budgeting, institutional mechanisms for gender responsive budgeting, budget development process, budget monitoring

\footnotetext{
${ }^{1}$ Full Professor, e-mail: zvonko.brnjas@ien.bg.ac.rs

${ }^{2}$ Research Associate, e-mail: mihajlo.djukic@ien.bg.ac.rs
} 


\section{Concept of Gender Responsive Budgeting - Theoretical Considerations}

Gender responsive budgeting (GRB) refers to applying the concept of gender equality within the process of development and implementation of local budgets. It is related to the analysis of the effects of budget revenues redistribution on life of men and women in local communities. This approach aims at establishing budget development procedures to match the needs of both men and women as local citizens, rather than developing separate budgets for each group. GSB is therefore strategic approach of allocation of assets for the purpose of implementation different policies, measures and programmes that might improve gender equality and support existing rich potentials in order to improve quality of everyday life. It tackles the issues of equal access to the resources, equal participation in decision making as well as benefits resulting from the use of local resources.

Applying GRB might have positive effects on local development and economic development in general. In that context, GRB represents significant incentive for development of certain economic sectors as well as economic activity and entrepreneurship in general, including direct and indirect consequences of its application in creating favourable institutional and business environment. Primary responsibility lies on local self-governments and other state institutions that should, through their policies, support application of the GRB and gender equality concept. Development of women entrenepreneurship for example, directly depends on readiness of the state to support favourable environment by facilitating solid access to the sources of funding, providing infrastructure support and simplyfing business regulation and procedures (Agrawal, 2017). In addition to institutional preconditions, adequate forms of training and education could be other supporting measures to influence progress in this field in Serbia. On the example of women in rural areas in Serbia, Munitlak-Ivanović states that creating business incubators and establishing special funds would create better conditions for more dynamic economic activity of this, particularly vulnerable, population (Munitlak Ivanović, 2016). Creating conditions for gender equality and equal treatment of men and women can activate additional developmental

potentials in particular sectors of the economy. Čeperković et al. indicate positive effects that the application of gender equality concept has on the development of the sector of tourism (Čeperković et al. 2017). 


\section{Institutional Mechanisms of Achieving Gender Equality in Local Self-Governments in Serbia ${ }^{3}$}

In line with the adoption of the Law on Gender Equality ${ }^{4}$ in December 2009 , establishment of the institutional mechanisms for gender equality (commissions, councils, persons of gender equality) in the units of local self-government (LSG) in the Republic of Serbia became mandatory. Depending on the statutes of the LSG and local administrative decisions, there have been established entities within the local assembly (local legislative authority) or the local government (local executive authority). The composition of these bodies is different. The members were sometimes elected from the roster of the local assembly members or regular citizens and associations, while sometimes the composition is mixed including both.

Institutional mechanisms for gender equality in Serbian LSG are mainly formed within the local assemblies, rarely within the local Government. This trend could be identified as one of the causes of systemic obstacles in the implementation of gender equality policy at the local level in Serbia. The lack of institutional mechanisms for gender equality at the executive level or their insufficient capacity lead to the lack of effective tools for gender policy implementation within local administration itself, as well as unrealistic expectations for the local assembly, often outside their regular mandates.

Typical for the most of local municipalities in Serbia is that the establishment of mechanisms for gender equality meets only the formal regulatory requirements and is not followed up by providing the necessary conditions for their work. Working conditions are, to the certain extent, limited by low technical capacities. They are also characterised by lack of resources available to other bodies, especially in local assemblies. The most important obstacle is related to the inexistence of formal procedures that could enable bodies in charge for gender equality to be involved in decision-making process. Additionally, important systemic deficiency refers to the lack of coop-

\footnotetext{
3 "Institutional Mechanisms for Gender Equality" is the term that, in a broader sense, determines the organizational body (entity) at all levels of government dealing with the position of women's position in a society. In this paper, attention has been paid to these mechanisms at the local level.

${ }^{4}$ Law on Gender Equality ("Official Gazete", No. 104/2009)
} 
eration with other administrative bodies and institutions as well as the users of the budget funds.

In general, it is not enough developed awareness and understanding that the area of gender equality is not a sector itself, but a cross-cutting issue influencing all other sectoral policies, programs and measures adopted at the level of local self-government. For that reason, cooperation between gender equality bodies and all other state institutions at the local level is indispensable in order to adequately incorporate the principles of gender equality into the system of local policies. To achive this goal, usually no additional budget funds are needed, and the favourable results could be achieved with the existing resources, fairly distributed within the planned programs and measures. In practice, institutional mechanisms for gender equality are either invisible or considered separately without formalized horizontal cooperation. Activities related to gender equality are usually personalized, being conducted on a voluntary basis. Eventual personal changes affect that the process is always starting from the very beginning. Moreover, development of the local budgets and the decision-making process is still not sufficiently transparent, and citizens as well as the civil sector and media are often not adequately involved/consulted.

Most of the activities that are of particular importance for the everyday life of citizens at the local level have been performed under the level of local municipality. It is therefore important for the local bodies to recognize the importance of incorporating the principles of gender equality into their programs, policies and measures funded from local government budgets. Within this process, it is crucial to include institutional mechanisms for gender equality in the process of planning, creating and decision-making in different sectors. Effective implementation of the mechanisms along with adequate local policies will contribute to the local development through applying the basic tools integrating gender equality into policies, namely gender statistics, gender budgeting and gender analysis.

\section{Establishment of the Cooperation Between the Mechanisms for Gender Equality and Other Local Self-Government Institutions}

The issue of gender equality is not the issue of one sector. It involves all segments of a society and affects almost all local government competencies and policies. Empirical findings suggest that the LSG practice in Serbia in this domain is not adequate and that in areas where coordination between 
the various sectors is essential, such as employment policy for example, objectives have not been achieved. Collaboration must be developed in a systematical manner, through dialogue between different bodies, keeping in mind how to achieve the best result, with the efficient use of resources, clear procedures and with the minimum level of bureaucracy.

There are several possible ways of cooperation between gender equality mechanisms and other entities at the local level. They include the exchange of information, consultation, dialogue, participation in decision-making and share of responsibility. Institutional mechanisms for gender equality should prepare action plans and establish cooperation with other local government units. The following table outlines potential ways of cooperation.

Table 1: Forms of co-operation between gender equality mechanisms and other entities

\begin{tabular}{|c|c|c|}
\hline $\begin{array}{c}\text { Forms of cooperation } \\
\text { between gender equality } \\
\text { mechanisms and other } \\
\text { local entities } \\
\end{array}$ & Ways of cooperation & Formalised cooperation \\
\hline $\begin{array}{l}\text { Exchange of information } \\
\text { Information as an input } \\
\text { Information as an output }\end{array}$ & $\begin{array}{l}\text { Meetings, informal } \\
\text { discussions and publi- } \\
\text { cations }\end{array}$ & $\begin{array}{l}\text { Memorandum on cooperation and ex- } \\
\text { change of information, defined number } \\
\text { and date of annual meetings. }\end{array}$ \\
\hline $\begin{array}{l}\text { Consultation } \\
\text { Listening and speaking }\end{array}$ & $\begin{array}{l}\text { Workshops, public } \\
\text { hearings, advisory } \\
\text { bodies and working } \\
\text { groups }\end{array}$ & $\begin{array}{l}\text { Submission of reports and inquiries for } \\
\text { opinion/feedback. }\end{array}$ \\
\hline Dialogue & Dialogue, conferences & $\begin{array}{l}\text { Initiation of formal dialogue on specific } \\
\text { issue to be tackled by the local community. }\end{array}$ \\
\hline $\begin{array}{l}\text { Decision-making participa- } \\
\text { tion }\end{array}$ & $\begin{array}{l}\text { Delegation, local coun- } \\
\text { cils, consulting activi- } \\
\text { ties }\end{array}$ & $\begin{array}{l}\text { Delegation of tasks to the local mechanism } \\
\text { (i.e. local mechanism could analyse gen- } \\
\text { der aspects in the field of agricultural } \\
\text { policy within local development strate- } \\
\text { gy/programme). }\end{array}$ \\
\hline Share of responsibility & $\begin{array}{l}\text { Joint management, } \\
\text { partnerships, contracts }\end{array}$ & $\begin{array}{l}\text { Joint development and implementation of } \\
\text { specific programme (i.e. prevention of } \\
\text { violence or economic empowerment) by } \\
\text { which gender equality mechanism has } \\
\text { defined responsibilities (preparation of } \\
\text { reports or share of information to the } \\
\text { public/state institutions, etc.) } \\
\text { Creation of joint teams working together } \\
\text { on specific topics (establishment of a team } \\
\text { for gender responsive budgeting). }\end{array}$ \\
\hline
\end{tabular}


Cooperation starts with the exchange of information as basic, the simplest and the least demanding form of cooperation. At this level, it is ensured that the actors in decision-making processes are equally informed. In the next step, the LSG bodies demonstrate their willingness to consult gender equality mechanisms on all issues that they can contribute in a relevant way, especially the ones that explicitly refer to gender equality. After consulting (opinion issue), we can move to a higher level of cooperation by establishing a dialogue in which the opinions and attitudes on concrete issues are exchanged in a critical and constructive manner. Finally, the most demanding and complex forms of co-operation relate to joint adoption, and then to joint implementation of decisions, as well as monitoring of their effects in gender-related segments.

\section{Types of Gender Responsive Budget Iniatives}

There are various gender responsive initiatives that could be raised by the local gender equality mechanisms or civil society organisations. Choosing one or couple of similar gender responsive budget initiatives to be raised depend on the mechanisms for gender equality and defined set of priorities. In that context, it is important to know the capacities of the local mechanism for the particular engagement and disposable resources. It should be underlined that the ultimate goal should be to create systemic solution and specific formal actions of the decision makers.

The basic types of budget initiatives as well as the main goals and the most important sources of these initiatives are presented in Table 2.

\section{Table 2: Types of Gender Responsive Budget Initiatives}

\begin{tabular}{|c|c|c|}
\hline $\begin{array}{c}\text { Name and description of } \\
\text { GRB initiative }\end{array}$ & Goals of GRB initiative & $\begin{array}{c}\text { Source of GRB initiative } \\
\text { and pre-conditions }\end{array}$ \\
\hline $\begin{array}{l}\text { Enabling participation of } \\
\text { citizens in the process of } \\
\text { local budget development. }\end{array}$ & $\begin{array}{l}\text { Identify important issues } \\
\text { and support their solution; } \\
\text { Incorporate the needs and } \\
\text { priorities of citizens into } \\
\text { funding priorities; } \\
\text { Obtain bi-directional com- } \\
\text { munication between citizens } \\
\text { and representatives of local } \\
\text { self-government regarding } \\
\text { the budget process; } \\
\text { Make the process of creat- }\end{array}$ & $\begin{array}{l}\text { This is a good example of } \\
\text { mobilising the local commu- } \\
\text { nity. Local community is } \\
\text { becoming interested in local } \\
\text { budgets, thus opening space } \\
\text { for future budget initiatives. } \\
\text { It is good if this initiative } \\
\text { could be among the first } \\
\text { initiatives and certainly part } \\
\text { of the broader budget discus- } \\
\text { sion, as well as to be com- }\end{array}$ \\
\hline
\end{tabular}




\begin{tabular}{ll}
\hline $\begin{array}{c}\text { Name and description of } \\
\text { GRB initiative }\end{array}$ & Goals of GRB initiative \\
\hline & $\begin{array}{l}\text { ing and making the budget } \\
\text { more transparent; } \\
\text { Stimulate the responsibility } \\
\text { of local self-government } \\
\text { towards citizens. }\end{array}$
\end{tabular}

Source of GRB initiative and pre-conditions bined with other gender budgeting initiatives.

\begin{abstract}
Implementation of the principle of gender equality in the creation, adoption and implementation of the local self-government budget and support in this process through the development of appropriate methodology.
\end{abstract}

When creating, adopting
and implementing the budg-
et, apply analytical tools
that will incorporate the
principles of gender equali-
ty into budget allocations
with an aim to improve the
status of women and im-
prove gender equality.

When creating, adopting et, apply analytical tools that will incorporate the principles of gender equality into budget allocations with an aim to improve the prove gender equality.
Envisage resources to create the assumptions for the application of genderresponsive budgeting in work of the local selfgovernment: statistics classified by gender, determination of needs of citizens, education on gender equality
This initiative assumes that local self-governments pos- sess the necessary knowledge, information and tools for its realization.
If they do not, then creating these assumptions should be a part of the initiative.

Creating systemic prerequisites for gender budgeting initiatives.

\section{Embed the gender perspec-} tive within the program proposals.
This initiative can be implemented independently or within other gender budgetinginitiatives.

\footnotetext{
Integrating gender equality into programs, program activities or projects planned by budget users and defining gender sensitive goals, activities and indicators.
}

\section{This initiative requires that we have knowledge of gender differences and problems. Professional support for budget users is essential during the process.}

\begin{abstract}
Reallocation of funds within a specific item or budget items: programs, program activities or projects that have already been approved for funding.
\end{abstract}

Change the pattern of
spending funds within one
or more programs, program
activities, or projects.

To initiate this type of change, it is necessary to conduct the analysis and collect relevant data (for example, gender analysis of program / program activity and / or projects financed from the local budgets). 


\begin{tabular}{lll}
\hline $\begin{array}{c}\text { Name and description of } \\
\text { GRB initiative }\end{array}$ & Goals of GRB initiative & $\begin{array}{l}\text { Source of GRB initiative } \\
\text { and pre-conditions }\end{array}$ \\
\hline $\begin{array}{l}\text { Introducing a new item or } \\
\text { budget item: new program, } \\
\text { program activity, or pro- }\end{array}$ & $\begin{array}{l}\text { Envisage the budget funds } \\
\text { for something that has not } \\
\text { ject. }\end{array}$ & $\begin{array}{l}\text { This initiative could be based } \\
\text { on analyses and indicators } \\
\text { that local self-government }\end{array}$ \\
& & $\begin{array}{l}\text { does not fulfill obligations } \\
\text { arising from different regula- } \\
\text { tions. }\end{array}$ \\
\hline
\end{tabular}

\section{The Mian Phases in the Process of Establishing Gender Responsive Local Budgets}

There are three key phases through which the budget process should go through to establish a gender-responsive budget (GRB) in the local selfgovernments (LSGs):

- Planning and data collection

- An analysis completed by making appropriate conclusions and

- Adopting the final conclusions

Figure 1: Key phases of gender-responsive budgeting process in LSGs

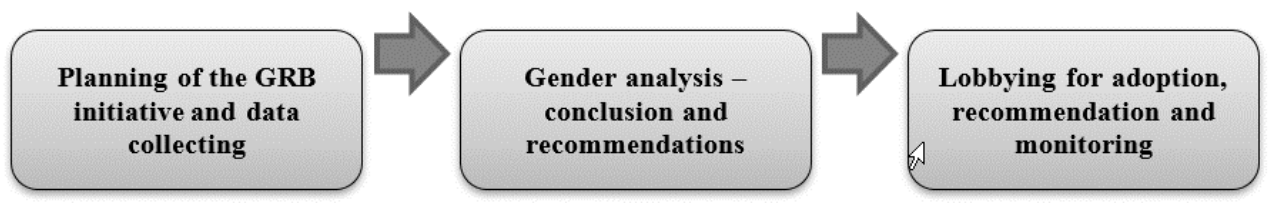

\section{Planning the GRB Initiatives and Collecting Data}

This phase represents the most important step in the gender analysis of the budget. The first step should be a detailed introduction to the budget process, i.e. understanding how the budget is created, adopted and executed, and the identification of the necessary documentary basis necessary for the analysis. In addition, the aim of this phase is to define the subject of the analysis and how to use the results (conclusions and recommendations) of the analysis. When defining what will be analyzed, it is determined what will be the subject of the analysis, what information is necessary, where these data will be sought and in which way, which actors are important and in what phase they should be involved in the process. 


\section{Gender Analysis}

\section{Defining the subject and the objectives of the analysis}

From the very beginning of the budget gender analysis, the most important question is what needs to be analyzed? Although almost any issue within the competence of local self-government can be viewed from the point of view of gender equality, not all the issues are equally important, i.e. of the equal priority for women and men in the local community, nor will their resolution have an equal impact on the quality of their daily lives. Options can be set in the following way:

- Identifying areas and programs where we well know the problems and needs to determine if these needs are met, how and what are the effects on the target group (for example: employment, entrepreneurship, violence against women, decision making, education, health, rural development, agriculture, etc.).

- Identifying the programs on which the largest portion of funds have been spent and the ongoing funding by local governments to determine whether women and men have equal opportunities and benefits from financing (for example, subsidies to agriculture or the economy, sports financing, subsidies in education - scholarships, etc., social services or one-time assistance for socially vulnerable groups), and what are the effects on users and beneficiaries

- Performing overall budget analysis in order to determine how funds from the local budget are spent, what are the priorities visible in the budget, which strategic documents are basis for the budget adoption, whether the budget process (its creation, adoption and implementation) is transparent?

- Choose all above mentioned options at the same time.

In selecting areas of particular relevance to gender equality, analysts should primarily rely on documents such as analyzes and strategic documents, action plans that exist in a particular area at a local, regional or state level. In addition to these documents, statistical data, analyzes and studies should be used to indicate specific problems faced by women and men, or needs of certain groups of women and men (for example: employment / unemployment, education and choice of occupations, social inclusion, etc.). Publications and existing body of research on gender issues and knowledge and experience of civil society are of special importance. 
In addition to determining the subject of analysis, it is equally important to ask what is to be achieved, i.e. which are the basic objectives of the analysis. The budget analysis process is often considering the effects of budget funding on men and women and providing specific conclusions, and recommendations. Recommendations can go in the direction of:

- Improvement of the existing programs in the form in which they are being implemented;

- Improvement of the existing programs with the aim of achieving or promoting gender equality;

- Cancelling the program because they did not show expected results;

- Suggesting new funding programs aimed at achieving or promoting gender equality and addressing specific community issues

When determining the subject of the analysis, it is necessary to determine the objectives of the analysis from a specific angle of gender equality. For example, this can be the following:

- To determine the representation of women and men, for example among beneficiaries of certain programs, i.e. whether funds are equally accessible to both;

- To determine how funds and other resources are distributed among women and men who are beneficiaries of a particular program;

- To determine the effects of the spent funds in relation to the planned goals;

- To determine whether the needs of the target group are met;

- To determine whether and which changes are needed;

- To determine the impact on gender equality.

\section{Data collection plan and determining data sources}

After defining the subject of gender analysis and its objectives, it is necessary to collect necessary data. Gender analysis is based on data classified by sex, and by gender statistics. One of the biggest challenges of each GRB initiative is the lack of or inaccessibility of gender-disaggregated data at the level of local self-government. If we do not have data on users of the funded programs sorted by sex, we cannot carry out a gender analysis. It is sometimes necessary to literally count users from the various lists. That is why the most common key recommendations of almost every GRB initiative in Serbia are aimed at ensuring that gender-disaggregated data is col- 
lected and processed at the local level. Specifically, it is supported by Gender Equality Law (Article 40), which explicitly requires statistical records.

\section{Mapping the key actors and determining attitudes towards them}

The next step in the process is mapping key actors and defining the form of cooperation with them. When mapping actors, attention should be paid to all three basic steps of GRB. The actors can be: institutions at all levels, local self-government bodies, councilors, non-governmental organizations, research institutes and faculties, media, local communities, other mechanisms for gender equality, individuals (i.e. experts) and others. It is necessary to create a list of actors and determine in which of the above phases / steps they are needed and what type of relationship is necessary to establish with them. Different expectations can be expected from different actors. Some of them need to be informed; the other expects to be consulted, especially when it comes to fixing problems and defining the priorities or providing support for the visibility of the community's GRB initiatives. It is useful at this stage to introduce the actors with planning activities and objectives of the budget process in order to timely determine expectations involving them from the very beginning in deciding about the goals of gender analysis.

\section{Conclusions and recommendations of gender analysis}

As soon as the first phase is completed, data processing and gender analysis can start. Gender analysis refers to processing and analyzing data related to gender. It is supposed to analyze the effects of measures and activities of planned programs, policies and projects on men and women. Gender analysis aims to help in identifying the gender patterns. The observed gender pattern does not always represent a problem. Therefore, it is important to define whether the observed gender pattern is a problem and maintain and/or produce inequality, and if the answer is yes, in what way; what are the causes and what are the consequences of the current situation? In order to be able to perform gender analysis, it is necessary to know the aspects of gender equality in the field of interest. Gender responsive budgeting is not just a matter of allocating resources, but also meeting the needs of women and men, bearing in mind the aspects of gender equality.

Obtained data are not of great importance if the needs and characteristics of the target group are not sufficiently determined. In other words, obtained data represent only the first phase in searching for the answer on the different questions, such are: what are the reasons behind the current data 
and relationships pattern? Therefore, at this stage, the process needs to be reversed in order to collect additional data, or to confirm or reject the original observations. When it comes to evaluating the effects of analyzed budget items on users, it may be important to maintain focus groups or individual interviews with users. Findings from the focus groups and the interviews are used as additional argumentation in the analysis. Regardless of the amount of useful information collected, it is important to stress that the report will include only those facts for which detailed elaboration has been provided, that are related to the subject, goals and important aspects of the gender equality analysis.

Budget analyses should be completed with concrete and practical recommendations. Defining recommendations as a basis for the successfull lobbying influenceing changes in the next budget year is time consuming process. Recommendations should be concrete, feasible and measurable including what should be done and why, who should do it and how, (i. e. how to do it).

The recommendations related to a specific problem for which the budget funds are required, and for which the local community does not deal with, should contain the following elements:

- Description of the problem

- Defining priorities

- Measure / program / policy for problem solving

- Key players in the implementation of the measure / policy

- Expected results

- Allocation of funds in the budget

- Argumentation on the benefits for local government of the proposed allocation

Recommendations for introducing gender aspects into the budget items should include the following elements:

- The result of gender analysis, i.e. the conclusion on the effects analyzed by the budget allocation on women and men and the consequences of the current situation on the quality of everyday life of women and men from the perspective of gender equality as well as the local community itself (access to services, resources, satisfaction of needs, development, etc.). 
- Concrete targeted recommendations for change with an explanation of the envisaged effects of the proposed change on the position of women/men, as well as benefits for the local community as a whole

\section{Advocacy for Adoption of Recommendations and Monitoring}

Advocating or lobbying activity is aimed at influencing decisionmaking through direct or indirect communication with specific decisionmakers. When it comes to lobbying, we are actually referring to direct or indirect impact on a particular person. Lobbying is, therefore, activity (or more activities) that affects a particular person or persons who have the power influence desired change. Lobbying is an important part of public advocacy. Public advocacy aims at systemic changes achieved through social action, from recognizing the problem to community mobilization, addressing it by involving citizens, the media and various stakeholders, to lobbying towards specific decision-makers.

\section{Conclusion}

The issue of gender-responsive budgeting is a very important aspect of gender equality in general. without creating the economic basis for gender equality, it is difficult to expect that this issue, which is considered as one of the most important segments of human rights, will be resolved in an appropriate way in any society. Following the adoption of the Law on Gender Equality Law in 2009, some progress in this field has been made in Serbia, including the one at the level of local self-governments. The focus of the paper was on the analysis of the establishment and functioning of special bodies, institutional mechanisms for gender equality at the level of local self-government. The research has shown that the mechanisms for gender equality in local governments in Serbia face numerous obstacles within their work, such as the insufficient importance paid to the issue of gender equality, insufficient visibility of these bodies in the structure of local selfgovernments, the abandonment of the responsibility of LSGs for their work or in cooperating with them, as well as the lack of measures to provide sufficient resources for their basic functioning, as well as resources that the local self-government allocate for programs, measures and policies that would contribute to the promotion of gender equality. 
In order to successfully overcome these obstacles in the following period, it is necessary to apply a set of policies and concrete measures. One of the most relevant areas is related to fostering a process of gender-responsive or sensitive budgeting at the local level. The precondition for this is the establishment of appropriate forms of cooperation between gender equality mechanisms and other entities in the LSGs, the initiation of a series of gender-responsive budget initiatives, and the establishment of an effective procedure for their implementation, monitoring and evaluation.

\section{Acknowledgements}

This paper is a part of research projects: 179015 (Challenges and prospects of structural changes in Serbia: Strategic directions for economic development and harmonization with EU requirements) and 47009 (European integrations and social and economic changes in Serbian economy on the way to the EU), financed by the Ministry of Education, Science and Technological Development of the Republic of Serbia.

\section{References}

[1] Agrawal, Reena, (2017). Contributions Made by Women Entrepreneurs in Augmenting Socio-Regional-Economic Growth of Emerging Market Economy. Journal of Women's Entrepreneurship and Education, (1-2), 87100.

[2] AQUIS - OSCE: Rodna ravnopravnost, OSCE Misija u Srbiji I Crnoj Gori, Odeljenje za demokratizaciju, Beograd, 2005

[3] Čeperković, Jelena; Šiljak, Marija; Đuradjević, Marijana. Women Entrepreneurship in Function of Improving Tourist Offer. Journal of Women's Entrepreneurship and Education, 2017, 3-4: 73-83.

[4] Dokmanović Mirjana, Rodna ravnopravnost $i$ javna politika, Ženski centar za demokratiju i ljudska prava, Subotica, 2002.

[5] Đurić Kuzmanović, Tatjana, Ka rodnom budžetiranju, Ženske studije i istraživanja i Futura publikacije, Novi Sad, 2007

[6] Evropska povelja o rodnoj ravnopravnosti na lokalnom nivou, Stalna konferencija gradova i opština, Beograd, 2009.

[7] OEBS, Institucionalni mehanizmi za postizanje rodne ravnopravnosti, Beograd, 2005.

[8] Izveštaj: Opštinska lica za rodnu ravnopravnost u Republici Srbiji, OSCE, Mission to Serbia, 31. decembar 2008. 
[9] Izveštavanje po Konvenciji o eliminaciji svih oblika diskriminacije nad ženama, Pokrajinski Zavod za ravnopravnost polova, Novi Sad, 2007.

[10] Konvencija o eliminisanju svih oblika diskriminacije žena, Republika Srbija, Ministarstvo rada i socijalne politike, Uprava za rodnu ravnopravnost, Beograd, novembar 2008

[11] Munitlak Ivanović, Olja. Possibilities for Development of Female Entrepreneurship in the Rural Areas. Journal of Women's Entrepreneurship and Education, 2016, 1-2: 79-96.

[12] Nacionalna strategija za poboljšanje položaja žena $i$ unapređivanje ravnopravnosti polova (2009-2015), Ministarstvo rada i socijalne politike, Uprava za rodnu ravnopravnost, Službeni glasnik RS, br. 55/05, 71/05ispravka, 101/07 i 65/08.

[13] Pojmovnik rodne terminologije - prema standardima Europske unije, Centar za ženske studije, uredila Rada Borić, Zagreb, 2007

[14] Putevi ostvarivanja rodne ravnopravnosti I jednakih mogućnosti - od ideje do prakse, Priručnik za službenike i organe lokalnih samouprava zadužene za ravnopravnost polova, Savet za ravnopravnost polova Vlade Republike Srbije, OEBS Misija u Srbiji, Beograd, 2007

[15] Uvođenje principa jednakosti I ravnopravnosti polova na lokalnom nivou vlasti, Priručnik za institucionalne mehanizme u lokalnoj upravi, Helsinški parlament građana, Banja Luka, 2007

[16] Zakon o izborima za jedinice lokalne samouprave, Službeni glasnik RS br. 129/2007

[17] Zakon o izboru narodnih poslanika, Službeni glasnik RS br. 35/2000

[18] Zakon o ravnopravnosti plova, Službeni glasnik RS br.104/2009

[19] Zakon o zaštitniku građana, Službeni glasnik br. 54/2007

Article history: $\quad$ Received: 9 November, 2018

Accepted: 10 December, 2018 